\title{
The Dilemma of Choosing a Vaccine Against SARSCoV2 in Children? /SARSCoV2 Vaccine in Children/
}

\author{
Kostic Andrijana ${ }^{2}$, Dajic Katerina ${ }^{2}$ and Stojkovic Andjelka ${ }^{1,2 *}$ \\ ${ }^{1}$ University of Kragujevac, Faculty of Medical Sciences, Department of Pediatrics, Serbia \\ ${ }^{2}$ Paediatric Clinic, University Clinical Center Kragujevac, Serbia
}

*Corresponding author: Andjelka Stojkovic, Faculty of Medical Sciences, Department of Pediatrics, University of Kragujevac, Svetozara Matkovica 69, Serbia

\section{ARTICLE INFO}

Received: 幽 October 13, 2021

Published: 蔧 October 20, 2021

Citation: Kostic Andrijana, Dajic Katerina, Stojkovic Andjelka. The Dilemma of Choosing a Vaccine Against SARSCoV2 in Children? /SARSCoV2 Vaccine in Children/. Biomed J Sci \& Tech Res 39(3)2021. BJSTR. MS.ID.006308.

\begin{abstract}
The rapid spread of the covid19 pandemic has posed a dilemma for us, should we vaccinate children against SARSCoV2 infection, with which type of vaccine, or should children be exposed to natural infection and stay unvaccinated? The prevention of COVID19 is more effective than the treatment of a child with COVID19 or long-COVID19, which is a kind of recommendation for vaccination of children against SARSCoV2. A new circumstance is the poor efficacy of previous vaccines, in adults, against new strains of SARSCoV2 and the fact that, in the September wave of the COVID19 pandemic, a worrying number of children became ill compared to previous waves. So far, only a few countries in the world have achieved vaccination coverage of over $80 \%$.
\end{abstract}

Keywords: COVID-19 Vaccines; SARS-CoV-2 Infection; Children's Health

\section{Introduction}

Vaccines for children are the basis for the prevention of serious, infectious diseases, which is why, for the last 6-7 decades, health workers have tried to keep the coverage of the population with vaccines over $90 \%$, at least in developed countries. The rapid spread of the covid19 pandemic has posed a dilemma for us should we vaccinate children against SARSCoV2 infection, with which vaccine (prepared by known technology or new technology), or should children be exposed to natural infection and stay unvaccinated? Pediatricians are daily exposed to pressure from certain pharmaceutical companies to vaccinate children older than 12 years with a certain vaccine, despite published and positive research on a vaccine that is applicable for children older than 3 years. Is this a simple match of pharmaceutical companies or is it a match between "new" and "old" vaccine technology or is it a fair match of scientific facts? Does the scientific and professional public, worldwide, agree that children should be vaccinated against SARSCoV2 infection, is there a safe and protective vaccine, and what age children should be included in the vaccination? Does vaccination of children against SARSCoV2 have a scientific justification after 18 months from the beginning of the COVID19 pandemic and after the arrival of new strains of SARASCoV2 against which the effectiveness of previous vaccines is partly because they don't protect against infection but protect against a severe clinical picture? Here we consider the achievements so far on the vaccine against SARSCoV2 infection in children.

Children are often asymptomatic COVID19 i.e. Children are significant carriers of SARSCoV2 in the community. Children suffer mainly from mild to moderate clinical pictures of COVID19. According to the American Academy of Pediatrics, so far an extremely small number of children have suffered from a severe clinical picture of COVID19 (2.4\% of total patients) or died of COVID19 $(0.08 \%$ of total patients), and these are children with comorbidities 
(obesity, diabetes, neurological progressive diseases) [1]. However children often show the long-COVID19 or post-COVID19, and these are predominantly children who were carriers of SARSCoV2 or suffered a mild clinical picture of COVID19. Long-COVID19 or postCOVID19 in children is mainly presented as a severe clinical picture in the form of the multisystem inflammatory syndrome (MISC) or similar-MISC which includes myocardial dysfunction, shock, and severe respiratory failure whose treatment is carried out in the intensive care unit.

Certainly, the prevention of COVID19 is more effective than the treatment of a child with COVID19 or long-COVID19, which is a kind of recommendation for vaccination of children against SARSCoV2. Indeed, there is an indication that children must be vaccinated against SARSCoV2 infection. We have been waiting for the results of research on adults for 18 months and accordingly, it is necessary to check the effectiveness of COVID19 vaccines in the child population, of course with the implementation of ethical principles of clinical research. A new circumstance is the poor efficacy of previous vaccines, in adults, against new strains of SARSCoV2 (delta, mu) and the fact that, in the September wave of the COVID19 pandemic, a worrying number of children became ill $(25.7 \%$ of the total number of patients) compared to previous waves [1].

The basic two groups of vaccines against SARSCoV2 infection are known and apply according to the technology of vaccine preparation. A total of 13 different vaccines are used worldwide. One group of vaccines was made by the known technology of vaccine production with whole, purified, inactivated SARSCoV2 (manufacturers: Sinopharm, Sinovac Biotech, Bharat Biotech) $[2,3]$. The second group of vaccines was made with a new vaccine production technology using:

1. mRNA against spike protein proteins (manufacturer: Pfizer BioNTech, Modern), or

2. Recombinant adenovirus as a vector against spike protein viruses (AstraZeneca, Institute of India, Janssen/ Johnson\&Johnson, Gamaleya National Center of Epidemiology and Microbiology, CanSinoBiologics), or

3. Recombinant spike protein with a new adjuvant (manufacturer: Novavax) or DNA plasmid [4,5].

The first three mentioned vaccine platforms have passed phase 3 and their effectiveness in the prevention of SARSCoV2 infection in adults has been confirmed, while research in the pediatric population is in the initial stages. Application of the fourth platform, i.e., the DNA vaccine began to be used in September 2021, in India, in adults and children older than 12 years [5], so we do not have data on its real effectiveness. We evaluate each vaccine according to its effectiveness, immunogenicity, and safety. Table 1 shows the basic characteristics of individual vaccines which are recommended for children. The efficacy of the inactivated vaccine against SARSCoV2 ranges from 50 to $83.5 \%$ [6]. The efficacy of a vaccine containing mRNA against the spike protein SARSCoV2 ranges from 94.1 to $95 \%$ [6]. The efficiency of the so-called "vector" vaccines against SARSCoV2 ranges from 65.7 to $91.6 \%$ [6]. The efficacy of a vaccine containing a recombinant spike protein with a new adjuvant is $89.7 \%$ [6]. The efficacy of the DNA vaccine, estimated in the laboratory, is $67 \%$ but is aimed at suppressing the delta strain of the SARSCoV2 virus [5,6].

To achieve high efficiency and immunogenicity of the vaccine, it is necessary to establish an efficient and known mechanism of immunization with phagocytosis using antigen-presenting or dendritic cells that activate T-lymphocytes, which will consequently activate B-lymphocytes, thus achieving cellular and humoral immune response. The second dose of the vaccine enhances and prolongs immunity against SARSCoV2 in terms of an increase in IgG antibody titer to the spike protein SARSCoV2 (S1-RBD) with neutralizing capacity, to a lesser extent to the N-protein SARSCoV2, as well as an increase in INF-gamma secretion after recognition of SARSCoV2 antigen, primarily CD4 lymphocytes and a lesser extent CD8 lymphocytes. Since the time of Pasteur, we have been considering the effectiveness of an inactivated ("dead") vaccine, that contains the entire infectious agent and conjugate vaccine that contains parts instead of the whole live virus. For example, pertussis vaccination coverage is $86 \%$ after 3 doses of vaccine (primarily whole-cell vaccine), which provided a low rate of pertussis in children [7]. It is this efficacy of the pertussis vaccine that can be compared with the efficacy of the inactivated SARSCoV2 vaccine $[2,3]$. Vaccines that use mRNA or DNA provide human cells with genetic information for an important part of SARSCoV2 against which the immune response is elicited. Vector vaccines transmit genetic information, through another virus for part of SARSCoV2, to human cells that produce a viral protein and elicit an immune response. Protein subunit vaccines produce proteins from viruses so that the human immune system learns to attack them.

Immunogenicity in previous studies was estimated as the percentage of seroconversion, i.e. Increase in the titer of neutral antibodies to SARS-CoV-2 after 28 days of vaccine administration. It is still not specified which antibody titer prevents infection or why there is a quantitative but not qualitative increase in anti-SARS-CoV antibodies after vaccination nor which CD4/CD8 lymphocyte ratio protects against SARSCoV2 infection nor how long post vaccination immunity lasts? The seroconversion achieved by the inactivated SARSCoV2 vaccine found in two independent studies in children was approximately the same: $96.8-100 \%$ according to the vaccine dose (1.5 and $3.0 \mathrm{mcg}$, respectively) compared to $100 \%$ after 56 days of the first dose, regardless of whether the dose was $4 \mathrm{mcg}$ or $8 \mathrm{mcg}$ and regardless of age group (3-5 years, 6-12 years, 1317 years) [2, 3]. In school-age children, seroconversion with the 
inactivated vaccine against SARSCoV2 is achieved after 28 days from the first dose [2]. The mRNA produced by Pfizer is $100 \%$ effective and contributes to a robust response by producing antibodies to SARSCoV2 in children aged 12-15 years after 7 days of the second dose of the vaccine $[4,8]$. The vaccine safety data in terms of the number of adverse local and systemic reactions in children are shown in Table $1[6,9,10]$. Data on the efficacy of other vaccines for adults are discussed in the English Covid Vaccination Program [6]. To achieve herd immunity, it is crucial to achieving coverage of the population by vaccination of approximately $80 \%$, which has been achieved by several countries in the world (Portugal, Spain, and Denmark). Until the achievement of collective immunity, it is necessary to implement epidemiological protection measures against the SARSCoV2 infection.

Table 1: Vaccines against SARSCoV2 applicable in children.

\begin{tabular}{|c|c|c|c|c|c|c|c|c|}
\hline $\begin{array}{c}\text { Vaccine } \\
\text { names (if } \\
\text { applicable) }\end{array}$ & $\begin{array}{c}\text { Vaccine } \\
\text { manufacturer }\end{array}$ & Type & $\begin{array}{c}\text { Target } \\
\text { population }\end{array}$ & Approval & Efficacy & $\begin{array}{c}\text { Safety } \\
\text { (adverse } \\
\text { reaction) }\end{array}$ & Immunogenity & $\begin{array}{c}\text { Manufacturer's } \\
\text { authorised } \\
\text { schedule }\end{array}$ \\
\hline $\begin{array}{c}\text { COVID19 } \\
\text { vaccine BIBP }\end{array}$ & Sinopharm & $\begin{array}{c}\text { Whole } \\
\text { inactivated } \\
\text { coronavirus }\end{array}$ & $\begin{array}{c}\text { Adults; } \\
\text { Children } 3 \\
\text { years and } \\
\text { older }\end{array}$ & WHO & $78.10 \%$ & $\begin{array}{c}\text { Fever (5.2- } \\
12.7 \%), \\
\text { Injection site } \\
\text { pain } 4-9.1 \% \text {, }\end{array}$ & $\begin{array}{l}100 \% \\
\text { seroconversion } \\
\text { at } 56 \text { days of } \\
\text { first vaccine in } \\
\text { all age gropus }\end{array}$ & $\begin{array}{c}2 \text { doses (3-4 } \\
\text { weeks apart); } 3 \\
\text { doses in some } \\
\text { cases }\end{array}$ \\
\hline CoronaVac & $\begin{array}{l}\text { Sinovac } \\
\text { Biotech }\end{array}$ & $\begin{array}{c}\text { Whole } \\
\text { inactivated } \\
\text { coronavirus }\end{array}$ & $\begin{array}{c}\text { Adults; } \\
\text { Children } 3 \\
\text { years and } \\
\text { older }\end{array}$ & WHO & $\begin{array}{c}50- \\
83.5 \%\end{array}$ & $\begin{array}{l}\text { Injection site } \\
\text { pain } 13 \% \\
\text { Fever } 5 \%\end{array}$ & $\begin{array}{c}96.8-100 \% \\
\text { seroconversion } \\
\text { at } 28 \text { days after } \\
\text { the second dose } \\
\text { of the } 3 \text { mcg of } \\
\text { vaccine in all age } \\
\text { groups }\end{array}$ & $\begin{array}{c}2 \text { doses (2-4 } \\
\text { weeks apart) }\end{array}$ \\
\hline $\begin{array}{l}\text { Comirnaty } \\
\text { BNT162b2 }\end{array}$ & $\begin{array}{c}\text { Pfizer } \\
\text { BioNtech }\end{array}$ & $\begin{array}{l}\text { mRNA vs } \\
\text { spike }\end{array}$ & $\begin{array}{c}\text { Adults; } \\
\text { Children } 12 \\
\text { years and } \\
\text { older }\end{array}$ & $\begin{array}{l}\text { MHRA, EMA, } \\
\text { FDA, WHO }\end{array}$ & $95 \%$ & $\begin{array}{c}\text { Injection } \\
\text { site pain } 79- \\
86 \% \text {, fatigue } \\
60-66 \% \text {, } \\
\text { headache } \\
55-65 \% \text {, some } \\
\text { severe allergic } \\
\text { reactions, } \\
\text { some } \\
\text { myocarditis } \\
\text { and } \\
\text { pericarditis }\end{array}$ & $\begin{array}{l}100 \% \text { at } 7 \text { day } \\
\text { after second } \\
\text { dose of vaccine }\end{array}$ & $\begin{array}{c}2 \text { doses (3 } \\
\text { weeks apart) }\end{array}$ \\
\hline ZyCoV-D & Zydus Cadila & $\begin{array}{l}\text { Circular } \\
\text { strands of } \\
\text { DNA }\end{array}$ & $\begin{array}{c}\text { Adults; } \\
\text { children } 12 \\
\text { years and } \\
\text { older }\end{array}$ & $\begin{array}{l}\text { India drug } \\
\text { agency }\end{array}$ & $67 \%$ & no data & no data & $\begin{array}{l}3 \text { doses (needle- } \\
\text { free device } \\
\text { pressed against } \\
\text { the skin) }\end{array}$ \\
\hline $\begin{array}{c}\text { Soberana } \\
\text { pediatria } \\
\text { clinica } 1 \\
\text { (FINLAY-FR-2 } \\
\text { and one dose } \\
\text { of FINLAY-FR- } \\
\text { 1A) }\end{array}$ & BioCubaFarma & $\begin{array}{l}\text { Conjugate } \\
\text { vaccine }\end{array}$ & $\begin{array}{c}\text { Children } 3 \\
\text { years and } \\
\text { older }\end{array}$ & $\begin{array}{l}\text { Cuban Center } \\
\text { for State } \\
\text { Control } \\
\text { of Drugs, } \\
\text { Medical } \\
\text { Devices and } \\
\text { Equipment } \\
\text { (CECMED) }\end{array}$ & $\begin{array}{c}62 \% \\
\text { after } \\
\text { only two } \\
\text { doses }\end{array}$ & $\begin{array}{c}\text { Injection site } \\
\text { pain }(20 \%), \\
\text { inflammation } \\
\text { at the } \\
\text { injection } \\
\text { site }(5 \%), \\
\text { and general } \\
\text { discomfort } \\
(5 \%)\end{array}$ & no data & $\begin{array}{c}2 \text { doses (4 } \\
\text { weeks apart) }\end{array}$ \\
\hline
\end{tabular}

\section{Acknowledgment}

Author (Andjelka Stojkovic) gratefully acknowledges his son for motivation.

\section{a. Availability of Data and Materials}

Wherever necessary, relevant citations are included in the reference section.

\section{b. Competing Interests}

The author has declared that no competing interest exists.

\section{References}

1. (2021) Children and COVID-19: State-Level Data Report. American Academy of Pediatrics, updated 09/20/2021.

2. Han B, Song Y, Li C, Yang W, Ma Q et al. (2021) Safety, Tolerability and Immunogenicity of an Inactivated SARS-CoV-2 Vaccine (CoronaVac) in Healthy Children and Adolescents: A Randomized, Double-Blind, and 
Placebo-Controlled, Phase 1/2 Clinical Trial. The Lancet Infect Dis online first.

3. Xia S, Zhang Y, Wang Y, Wang H, Yang Y, et al. (2021) Safety and immunogenicity of an inactivated SARS-CoV-2 vaccine, BBIBP-CorV: a randomized, double-blind, placebo-controlled, phase $1 / 2$ trial. The Lancet Infect Dis 21(1): 39-51.

4. (2021) Pfizer-BioNTech COVID-19 Vaccine Overview and Safety (also known as COMIRNATY). Centers for Disease Control and Prevention updated Sep.20, 2021.

5. Silveira MM, Moreira GMSG, Mendonça M (2021) DNA vaccines against COVID-19: Perspectives and challenges. Life Sciences 267: 118919.

6. (2021) COVID-19 vaccination program: Information for healthcare practitioners. Public Health England. Last updated 6 August 2021.

\section{ISSN: 2574-1241}

DOI: $10.26717 /$ BJSTR.2021.39.006308

Stojkovic Andjelka. Biomed J Sci \& Tech Res

This work is licensed under Creative

Commons Attribution 4.0 License

Submission Link: https://biomedres.us/submit-manuscript.php
7. (2015) Pertussis vaccines: WHO position paper - 28 August 2015 (2015) Weekly epidemiological record (90); 35: 433-460.

8. Frenck RW Jr, Klein NP, Kitchin N, Gurtman A, Absalon J, et al. (2021) C4591001 Clinical Trial Group. Safety, Immunogenicity, and Efficacy of the BNT162b2 Covid-19 Vaccine in Adolescents. N Engl J Med. 2021 Jul 15 385(3): 239-250.

9. (2021) Vaccine information fact sheet for recipients and caregivers about comirnaty (covid-19 vaccine, mRNA) and Pfizer-Biontech covid-19 vaccine to prevent coronavirus disease 2019 (covid-19). Revised 22 Sep 2021.

10. Valdes-Balbin Y, Santana-Mederos D, Quintero L, Sonsire Fernández, Laura Rodriguez, et al. (2021) SARS-CoV-2 RBD-Tetanus toxoid conjugate vaccine induces a strong neutralizing immunity in preclinical studies. BioRxiv 2021.02.08.430146.

$\begin{array}{ll}\text { BIOMEDICAL } & \text { Assets of Publishing with us } \\ \text { RESEARCHES } & \text { - Global archiving of articles } \\ \text { - Immediate, unrestricted online access } & \text { - Rigorous Peer Review Process } \\ \text { isSN: 2574-1241 } & \text { - Authors Retain Copyrights } \\ & \end{array}$

